\title{
Gestational trophoblastic disease: a ten-year review
}

\author{
Ciążowa choroba trofoblastyczna: 10-letni przegląd
}

\author{
1 Department of Obstetrics \& Gynaecology, School of Medical Sciences, Universiti Sains Malaysia, Kelantan, Malaysia \\ ${ }^{2}$ Department of Obstetrics \& Gynaecology Hospital Sultanah Aminah, Johor Baharu, Malaysia \\ Correspondence: Dr Erinna Mohamad Zon, Department of Obstetrics \& Gynaecology, School of Medical Sciences, University Sains Malaysia, Jalan Raja Perempuan Zainab II, Kubang Kerian, 16150, Kelantan, \\ Malaysia, tel.: +60122283755, e-mail: erinna@usm.my
}

\begin{abstract}
Objectives: To determine the prevalence of different types of gestational trophoblastic disease, assess the factors involved in malignant conditions and to determine treatment outcomes. Methodology: A retrospective review was conducted to investigate all gestational trophoblastic disease cases from January 2002 to December 2011. Results: A total of 123 patients were diagnosed with gestational trophoblastic disease within ten years, including 98 cases of benign and 25 cases of malignant gestational trophoblastic disease. There were $53(43.1 \%)$ patients with partial and $45(36.6 \%)$ with complete hydatidiform mole. Malignant forms accounted for 25 (20.3\%), persistent trophoblastic disease for $22(17.9 \%)$ and choriocarcinoma for $3(2.4 \%)$ cases. The risk of developing malignant gestational trophoblastic disease increased by $5 \%$ every year of life. Twenty-two women received methotrexate, including 19 stage I patients receiving single-agent methotrexate, with complete recovery achieved in 12 patients (63\%). Seven stage I patients put on actinomycin D achieved complete recovery (37\%). Three patients with choriocarcinoma received EMA-CO regimen as treatment. Conclusion: We estimated the prevalence of gestational trophoblastic disease at 2.8 in 1,000 pregnancies, which is higher compared to Europe/USA. The risk factors for malignant disease included age, high parity, and long interval since the last child birth. Standard treatment allows for favorable outcomes.
\end{abstract}

Keywords: molar pregnancy, gestational trophoblastic disease, gestational trophoblastic neoplasia, choriocarcinoma, partial mole

Streszczenie Cel pracy: Określenie częstości występowania różnych typów ciążowej choroby trofoblastycznej, ocena czynników przyczyniających się do rozwoju postaci złośliwych oraz determinujących wyniki leczenia. Metody: Prospektywne badanie mające na celu analizę wszystkich przypadków ciążowej choroby trofoblastycznej rozpoznanej w okresie od stycznia 2002 do grudnia 2011 roku. Wyniki: W ciągu 10 lat ciążową chorobę trofoblastyczną zdiagnozowano u 123 pacjentek, w tym postać łagodną i złośliwą odpowiednio u 98 i 25 kobiet. Obecność zaśniadu groniastego częściowego stwierdzono u 53 (43,1\%), a całkowitego u 45 (36,6\%) pacjentek. Postać złośliwa dotyczyła 25 (20,3\%) przypadków, przetrwała choroba trofoblastyczna 22 (17,9\%), natomiast kosmówczak 3 (2,4\%). Ryzyko wystąpienia złośliwej postaci ciążowej choroby trofoblastycznej z każdym rokiem życia wzrastało o 5\%. Leczenie metotreksatem zastosowano u 22 kobiet, w tym w monoterapii u 19 pacjentek w stadium I zaawansowania choroby; wyzdrowienie całkowite odnotowano u 12 (63\%) pacjentek. U 7 pacjentek w stadium I, które otrzymały terapię aktynomycyną D, osiągnięto pełną remisję (37\%). U 3 pacjentek z kosmówczakiem stosowano schemat leczenia EMA/CO. Wnioski: Oszacowana przez nas częstość występowania ciążowej choroby trofoblastycznej wyniosła 2,8 na 1000 ciąż - jest to wartość wyższa niż w Europie i USA. Czynniki ryzyka wystąpienia postaci złośliwej obejmowały wiek, wysoką liczbę ciąż oraz długi czas od ostatniego porodu. Standardowa terapia pozwala na uzyskanie korzystnych wyników leczenia.

Słowa kluczowe: zaśniad groniasty, ciążowa choroba trofoblastyczna, ciążowa neoplazja trofoblastu, kosmówczak, zaśniad groniasty częściowy 


\section{INTRODUCTION}

$\mathrm{G}$ estational trophoblastic disease (GTD) forms a group of disorders spanning from complete and partial molar pregnancies to malignant conditions, such as invasive mole, choriocarcinoma and the very rare placental site trophoblastic tumor (PSTT). There are only a few reported cases on neoplastic transformation of atypical placental site nodules to placental site trophoblastic tumor. The World Health Organization (WHO) classifies trophoblastic diseases into premalignant conditions, such as partial and complete hydatidiform moles, and malignant conditions, such as persistent trophoblastic disease (PTD), invasive mole, choriocarcinoma, and placental site tumors.

Molar pregnancies can be subdivided into complete (CM) and partial moles (PM), based on genetic and histopathological features. Complete moles are diploid and androgenic in origin, with no evidence of fetal tissue. Complete moles usually $(75-80 \%)$ arise as a consequence of duplication of a single sperm following fertilization of an 'empty' ovum. Some complete moles (20-25\%) can arise after dispermic fertilization of an 'empty' ovum. Partial moles are usually (90\%) triploid in origin, with two sets of paternal haploid genes and one set of maternal haploid genes. Partial moles occur, in almost all cases, following dispermic fertilization of an ovum. Ten percent of partial moles represent tetraploid or mosaic conceptions. In a partial mole, there is usually evidence of a fetus or fetal red blood cell( ${ }^{(1)}$. Risk factors for GTD include age $<15$ years and $>50$ years, nulliparity, low socioeconomic background, dietary protein and carotene deficiency. Previous history of molar pregnancy will increase the risk by 20 to 40 times, and the overall recurrence rates are $5 \%{ }^{(2)}$.

The treatment in GTD depends on the subtype of the disease and is based on clinical examination, and histopathological examination (HPE) report of the product of conception.

In general, the prognosis in the majority of patients with any form of GTD remains excellent. Most patients require primary treatment for non-malignant conditions; however, patients with malignant GTD may pose a challenge for the gynecologists. Despite the good prognosis and a wide range of treatment options, it needs long-term follow-up and careful, close monitoring of patients for relapse. An advanced disease could be difficult to treat and it may carry a poor prognosis.

We conducted this retrospective study to determine the prevalence and outcomes of GTD in our center and assess the risk factors for GTD.

\section{MATERIALS AND METHODS}

The study was ethically approved by the Research Ethical Committee, Hospital Universiti Sains Malaysia (HUSM). Permission to review patients' medical records was granted by the Director of HUSM.

\begin{tabular}{|c|c|c|}
\hline Malignancy & Frequency $(\boldsymbol{n})$ & Percentage (\%) \\
\hline No & 98 & 79.7 \\
\hline Yes & 25 & 20.3 \\
\hline Total & 123 & 100 \\
\hline
\end{tabular}

Tab. 1. Malignant and non-malignant form of GTD diagnosed at HUSM

\begin{tabular}{|c|c|c|}
\hline Classification & Frequency $(n)$ & Percentage (\%) \\
\hline Hydatidiform mole* & 98 & 79.7 \\
\hline Choriocarcinoma & 3 & 2.4 \\
\hline PTD & 22 & 17.9 \\
\hline Total & 123 & 100 \\
\hline
\end{tabular}

Tab. 2. Types of GTD according to clinical diagnosis at HUSM

\begin{tabular}{|c|c|c|}
\hline Diagnosis & Frequency $(\boldsymbol{n})$ & Percentage (\%) \\
\hline Partial mole & 64 & 52.1 \\
\hline Complete mole & 56 & 45.5 \\
\hline Choriocarcinoma & 3 & 2.4 \\
\hline Total & 123 & 100 \\
\hline
\end{tabular}

Tab. 3. Types of GTD according to histopathological diagnosis at HUSM

\begin{tabular}{|c|c|c|}
\hline Type & Frequency $(\boldsymbol{n})$ & Percentage (\%) \\
\hline $\begin{array}{c}\text { Persistent trophoblastic } \\
\text { disease }\end{array}$ & 22 & 17.9 \\
\hline Choriocarcinoma & 3 & 2.4 \\
\hline Total & 25 & 20.3 \\
\hline
\end{tabular}

Tab. 4. Types of gestational trophoblastic neoplasia in HUSM

All patients with GTD treated between January 2002 and December 2011 were included in the study, and medical records were traced from the Hospital Record and Archive Office. To narrow down the search, the following diagnosis keywords in accordance with the International Classification of Diseases (ICD-9 and ICD-10) were used: "Hydatidiform Mole," "Persistent Trophoblastic Disease," Choriocarcinoma" and "Invasive Mole." For standardization, the FIGO (International Federation of Gynecology and Obstetrics)/WHO 2003 staging for gestational trophoblastic neoplasia was used and confirmed by HPE. Patients with non-gestational choriocarcinoma or with other concurrent cancer and incomplete data were excluded. All relevant data including patient demography (age, parity, race, occupation, body mass index - BMI and present status), diagnosis, risk factors (pre-treatment serum beta hCG level, size of uterus at presentation by clinical and ultrasound assessment, associated hypertension and thyrotoxicosis at presentation), ultrasound findings, obstetric and gynecologic history, medical history, family history, drug history, signs and symptoms, pre-treatment radiological findings, staging, primary treatment and follow-up were entered into the Data Collection form and analyzed. Statistical data analysis was performed using the computer IBM ${ }^{\star}$ SPSS ${ }^{\bullet}$ Statistics version 22.0 software. 


\begin{tabular}{|c|c|c|c|c|}
\hline \multirow{3}{*}{ Variables } & \multicolumn{4}{|c|}{ GTD $(n=123)$} \\
\hline & \multicolumn{2}{|c|}{ Benign (Partial/complete mole) $(n=98)$} & \multicolumn{2}{|c|}{ Malignant (Choriocarcinoma/PTD) $(n=25)$} \\
\hline & Mean (SD) & Frequency (\%) & Mean (SD) & Frequency (\%) \\
\hline Age [years] & $33.50(10.21)$ & & $38.84(11.02)$ & \\
\hline $\begin{array}{l}\text { Ethnicity: } \\
\text { • Malay } \\
\text { • non-Malay }\end{array}$ & & $\begin{array}{c}90(91.80) \\
8(8.20) \\
\end{array}$ & & $\begin{array}{c}24(96.00) \\
1(4.00) \\
\end{array}$ \\
\hline $\begin{array}{l}\text { Education level: } \\
\text { - below tertiary } \\
\text { - tertiary \& above }\end{array}$ & & $\begin{array}{l}30(60.00) \\
20(40.00) \\
\end{array}$ & & $\begin{array}{l}96(77.41) \\
28(22.59) \\
\end{array}$ \\
\hline $\begin{array}{l}\text { Occupation: } \\
\text { - employed } \\
\text { - unemployed }\end{array}$ & & $\begin{array}{l}85(86.70) \\
13(13.30) \\
\end{array}$ & & $\begin{array}{c}6(24.00) \\
19(76.00) \\
\end{array}$ \\
\hline Parity & $3.49(3.04)$ & & $4.72(3.47)$ & \\
\hline Age of menarche [years] & $13.11(1.21)$ & & $12.80(0.87)$ & \\
\hline Weight $[\mathrm{kg}]$ & $57.15(11.29)$ & & $57.67(10.38)$ & \\
\hline Last child birth [years] & $3.62(3.68)$ & & $6.24(6.82)$ & \\
\hline Pre- $\beta$-HCG & $302081.42(423863.97)$ & & $274176.32(225835.26)$ & \\
\hline Uterine clinical size & $15.80(3.23)$ & & $16.56(3.58)$ & \\
\hline Uterine size on ultrasound & $11.51(2.82)$ & & $11.52(2.87)$ & \\
\hline Molar diameter & $7.31(2.34)$ & & $7.52(2.80)$ & \\
\hline $\begin{array}{l}\text { Previous miscarriage: } \\
\text { - no } \\
\text { - yes } \\
\end{array}$ & & $\begin{array}{l}86(87.80) \\
12(12.20) \\
\end{array}$ & & $\begin{array}{c}23(92.00) \\
2(8.00) \\
\end{array}$ \\
\hline $\begin{array}{l}\text { Previous OCP: } \\
\text { - no } \\
\text { - yes } \\
\end{array}$ & & $\begin{array}{c}92(93.90) \\
6(6.10) \\
\end{array}$ & & $\begin{array}{c}24(96.00) \\
1(4.00) \\
\end{array}$ \\
\hline $\begin{array}{l}\text { Thecal cyst: } \\
\text { - no } \\
\text { - yes }\end{array}$ & & $\begin{array}{c}92(93.90) \\
6(6.10)\end{array}$ & & $\begin{array}{c}21(84.00) \\
4(16.00)\end{array}$ \\
\hline
\end{tabular}

Tab. 5. Descriptive statistics of variables of factors associated with GTD

\section{RESULTS}

\section{The prevalence of different types of GTDs}

A total of 123 cases were diagnosed with GTD during ten years, including 98 cases of benign and 25 cases of malignant GTD (Tab. 1). Among the benign forms of GTD, there were $53(43.1 \%)$ patients with partial hydatidiform mole and 45 (36.6\%) with complete hydatidiform mole diagnosed clinically (Tab. 2) and confirmed by HPE (Tab. 3). Malignant form of GTD accounted for a total of $25(20.3 \%)$ cases, including PTD in $22(17.9 \%)$ and choriocarcinoma in $3(2.4 \%)$ patients (Tab. 4).

\section{Risk factors for malignant vs. premalignant condition}

The risk factors of malignant disease included age, ethnicity, pre-treatment hCG level, parity, child birth spacing, uterine size, size of molar tissue, history of molar pregnancy, previous use of oral contraceptives and the presence of theca lutein cyst (Tab. 5). Among the risk factors, age was strongly correlated with malignant GTD. It was found that the risk of malignant GTD increased by $5 \%$ with every year of life (Tab. 6).

\section{The outcomes of suction and curettage, MTX regimen and EMA-CO regimen in patients with gestational trophoblastic neoplasia treated at HUSM}

We analyzed the outcomes in two major treatment groups, namely MTX (methotrexate) regimen and EMA-CO (etoposide, methotrexate, and dactinomycin alternating with cyclophosphamide and vincristine) regimen. A total of 22 patients received MTX as a single agent therapy and all of them were diagnosed with PTD; there were 19 patients with FIGO stage I disease, one patient with FIGO stage II disease, one patient with stage III and one with stage IV disease. Stage II and III patients needed second-line chemotherapy with actinomycin D and achieved full recovery; 19 stage I patients received single-agent MTX and complete recovery was achieved in 12 patients, resulting in a success rate of $63 \%$ when used a single agent in stage I disease. There were 7 patients with stage I disease who failed to achieve satisfactory response with MTX alone and eventually required actinomycin D (37\%) to achieve complete recovery. In this study, 3 patients diagnosed with choriocarcinoma, including 2 patients with stage I disease, received EMA-CO regimen. One of them had hysterectomy done prior to treatment with EMA-CO and another received only EMA-CO after evacuation. Another patient 


\begin{tabular}{|c|c|c|c|c|}
\hline Variables & Crude $\beta$ & Crude OR (95\% Cl) & Wald (df) & $p$-value \\
\hline Age & 0.05 & $1.05(1.01,1.10)$ & $4.92(1)$ & 0.027 \\
\hline Parity & 0.12 & $1.13(0.98,1.29)$ & $2.96(1)$ & 0.085 \\
\hline Weight & 0.01 & $1.00(0.97,1.05)$ & $0.04(1)$ & 0.833 \\
\hline B-HCG & $<0.001$ & $1.00(1.00,1.00)$ & $0.10(1)$ & 0.751 \\
\hline Age of menarche & -0.26 & $0.77(0.50,1.18)$ & $1.45(1)$ & 0.228 \\
\hline Uterus (ultrasonography) & 0.001 & $1.00(0.86,1.17)$ & $<0.001(1)$ & 0.986 \\
\hline Molar diameter & 0.04 & $1.04(0.87,1.24)$ & $0.15(1)$ & 0.695 \\
\hline $\begin{array}{l}\text { Thecal cyst: } \\
\cdot \text { no } \\
\text { - yes }\end{array}$ & -1.07 & $\begin{array}{c}1.00 \\
2.92(0.76,11.28) \\
\end{array}$ & $2.42(1)$ & 0.12 \\
\hline $\begin{array}{l}\text { Last child birth: } \\
\cdot 1-4 \text { years } \\
\cdot \geq 5 \text { years }\end{array}$ & 1.40 & $\begin{array}{c}1.00 \\
4.06(1.52,10.87) \\
\end{array}$ & $7.80(1)$ & 0.005 \\
\hline Previous miscarriage & -0.47 & $0.62(0.13,2.98)$ & $0.35(1)$ & 0.554 \\
\hline Previous OCP & -0.45 & $0.64(0.07,5.56)$ & $0.17(1)$ & 0.685 \\
\hline
\end{tabular}

Tab. 6. Risk factors for malignant form of GTD in HUSM based on simple logistic regression analysis

had stage IV disease with brain and liver metastasis. She was primarily started on EMA-CO, but eventually died. The remaining 2 patients had complete remission after treatment with EMA-CO. The outcomes in patients with GTD indicate complete recovery rate of $98 \%$.

\section{DISCUSSION}

The study included all patients with any form of GTD seen and primarily managed at HUSM over the period of ten years, from $1^{\text {st }}$ January 2002 to $31^{\text {st }}$ December 2011 . A total of 160 patients' records were reviewed and 123 records were selected, studied and analyzed according to inclusion and exclusion criteria. All the records were reviewed following the described methodology.

The prevalence of GTD differs dramatically in different regions. The incidence is higher in Asia and Latin America compared to North America and Europe.

GTD (hydatidiform mole, invasive mole, choriocarcinoma, placental-site trophoblastic tumour) is a rare entity in the UK, with a calculated incidence of $1 / 714$ live births compared to a recorded rate of 0.2 to 1.5 per 1,000 live births in Europe and North American region. There is evidence of ethnic variation in the incidence of GTD in the UK, with a higher incidence in Asian compared with nonAsian women (1/387 versus 1/752 live births). However, these figures may under-represent the true incidence of the disease due to reporting problems, particularly in regard to partial moles ${ }^{(2)}$. GTN may develop after a molar pregnancy, a non-molar pregnancy or a live birth. The incidence after a live birth is estimated at 1/50,000. Due to the rarity of the problem, an average consultant obstetrician and gynecologist may deal with only one new case of molar pregnancy every second year ${ }^{(3)}$. It is now easier to diagnose GTD (particularly hydatidiform mole) in the first trimester as a result of hCG determinations and/or sonography (particularly transvaginal). Indeed, these two tests (beta subunit hCG and sonography) are invaluable in the diagnosis, management, and follow-up of GTD tumours. Urine or serum levels of hCG correspond to the number of viable tumour cells.

In HUSM, the prevalence was similar to the national rate, i.e. about 2.5 per 1,000 pregnancies on average for the past ten years.

Among 98 cases of benign GTD, there were 53 (43.1\%) patients with partial hydatidiform mole and 45 (36.6\%) with complete hydatidiform mole diagnosed clinically and confirmed by histopathological evaluation. Malignant GTD accounted for a total of $25(20.3 \%)$ patients, including 22 (17.9\%) patients with PTD and 3 (2.4\%) patients with choriocarcinoma.

According to histopathological diagnosis, 64 (52\%) patients had partial hydatidiform mole on tissue evaluation followed by complete hydatidiform mole in 56 patients (45.5\%) and the remaining 3 patients had histopathological diagnosis of choriocarcinoma.

It is known that approximately $15 \%$ of patients after evacuation of complete mole develop $\mathrm{PTD}^{(4)}$, and the risk of developing PTD after a partial hydatidiform mole is about 2 to $4 \%$. In this study, 11 (20.8\%) patients with partial hydatidiform mole eventually developed PTD and another $11(24.4 \%)$ patients from complete hydatidiform mole group developed PTD. All of the patients had follow-up at our Molar clinic HUSM after suction and curettage (S\&C), serial serum hCG monitoring was done, almost all of these patients were diagnosed with PTD due to plateauing serum hCG level three to six weeks after S\&C; 2 patients had persistent per vaginal bleeding; patients from both groups required single-agent MTX and, occasionally, second-line chemotherapy with actinomycin D. All patients were diagnosed using the RCOG criteria recommended for the diagnosis of PTD. The reported incidence of choriocarcinoma is approximately 2 to $5 \%$ in all cases of GTD. In North America and Europe, the incidence is around 1 in 10,000 to 1 in 40,000 pregnancies, and it is much higher in Asian countries, i.e. 1:6,000. Choriocarcinoma following a hydatidiform 
mole is a more common occurrence. In this study, 3 patients $(2.4 \%)$ developed gestational choriocarcinoma over the period of 10 years, as confirmed by histopathological diagnosis.

All patients recruited in this study were diagnosed and classified according to FIGO $2009^{(5)}$ anatomical staging system for GTD. Most patients $(119,96.7 \%)$ had stage I disease, with the tumor confined to the uterus. They were followed by stage II and stage III patients (with one patient each), and finally there were $2(1.6 \%)$ patients with stage IV disease and brain metastasis.

Our review showed that the majority of our cases were benign GTDs, predominantly partial hydatidiform mole, followed by complete hydatidiform mole. Malignant cases accounted for less than half of our total GTD population, with the majority of PTDs and only 3 cases of choriocarcinoma. This finding certainly reflects on the general opinion that most GTDs are benign with a handful of them being malignant.

The patients' age ranged between 18 and 54 years. The peak incidence of benign disease was found in age between 20 and 30 years $(90 \%)$, while the peak incidence of malignant disease was found to be in the range of 40 to 50 years (90\%); most patients in the benign group were aged less than 30 years, whereas those in the malignant group were mostly above 40 years of age. The mean age in this benign group was 33.5 years and the mean age in the malignant group was 38.84 years. Multiple logistic regression analysis showed that there was a significant association between age and malignancy. It was found that the risk of developing malignant GTD increased by $5 \%$ with every year of life (95\% confidence interval, CI 1.01, 1.10). The risk increased by $5 \%$ with every year of life in $95 \%$ of the study population $(p=0.029)$. Again, it is seen that age is a significant factor for developing malignant $\mathrm{GTN}^{(6)}$.

The highest incidence of malignant GTD occurred in the high parity group, mean para was $4.72,57 \%$ of patients were para 5 and above; according to some studies, multiparity is a risk factor for $\mathrm{GTN}^{(5)}$. However, in this study the correlation of parity with GTN was not statistically significant $(p \leq 0.085)$.

The level of pre-treatment serum beta hCG has long been associated with the increased risk of malignant GTD. In this study, the mean pre-treatment hCG level was similar in both benign and malignant group: 302,081 IU/L and $274,176 \mathrm{IU} / \mathrm{L}$, respectively. However, $80 \%$ of women who were destined to develop malignant disease had initial hCG level of 200,000 IU/L or more ${ }^{(7,8)}$.

In this study, the interval since last child birth was analyzed to determine the association with malignant disease. The mean interval was 3.62 years in the benign group and 6.24 years in the malignant group. It appears that mothers who were pregnant again after a period of more than 6 years were at a risk of developing malignant disease $(p \leq 0.005)$; however, not many studies have actually looked into the interval between pregnancies as an independent risk factor, and this finding needs to be correlated with maternal age at the time of conception, which was not done in this study. The measurement of uterine size and the size of the molar tissue was done by ultrasound, with the largest diameter expressed in centimeters $(\mathrm{cm})$. The mean uterine size prior to evacuation was similar in both groups: $11.52 \mathrm{~cm}$ in benign group and $11.52 \mathrm{~cm}$ in malignant group, while the largest diameter of molar tissue was $7.31 \mathrm{~cm}$ in benign group and $7.52 \mathrm{~cm}$ in malignant group. There was no significant correlation between uterine size or the size of molar tissue and malignant disease in this study, which corresponds to other similar studies ${ }^{(9)}$.

The presence of theca lutein cyst was evaluated using ultrasound to identify the relationship with malignant disease, with cysts with the largest diameter $>4 \mathrm{~cm}$ included in the analysis $^{(10)}$. Only $6.1 \%$ patients in the benign group had thecal lutein cyst compared to $16 \%$ of patients with lutein cyst in the malignant group $(p \leq 0.12)$. Some studies suggest the association between lutein cyst and malignancy ${ }^{(11)}$; however, there is need for a large scale study to prove this association with significance.

Twelve patients (12.20\%) in the benign group and 2 patients $(8 \%)$ in the malignant group had previous history of miscarriage. Similar rates of miscarriage were observed in both groups, and therefore previous miscarriage did not appear to be statistically significant in increasing the risk of malignant GTD.

According to studies, previous history of molar pregnancy increases the risk of molar pregnancy by 1 to $2 \%^{(7,12)}$; however, it does not appear to specifically cause persistent disease in future. In this study, none of the patients in the benign group had previous history of molar pregnancy and 2 patients (8\%) in the malignant group had previous molar pregnancy. The relationship between previous molar pregnancy and malignant GTD failed to reach any statistical significance in this study.

Oral contraceptives appear to increase the relative risk of molar pregnancy by 1.1 to $2.6 \%{ }^{(10)}$; however, they do not appear to increase the risk of malignant $\mathrm{GTN}^{(9)}$. In this study, 6 patients $(6.1 \%)$ who had benign disease were on oral contraceptives (OCP) previously and only one woman in the malignant group was using OCPs. The use of OCPs did not appear to increase the risk of malignant GTD; however, we did not take the type or duration of OCP use into consideration in this study due to unavailable information, thus we are unable to safely conclude if the use of OCPs really increases the risk of malignant disease.

Among all the associated risk factors discussed above, patient's age appears to be the most important and a significant risk factor for malignant GTD. It was statistically proven in $95 \%$ of the study population that the risk of developing malignant GTD increases by $5 \%$ with every year of life (95\% CI, $p \leq 0.029)$.

All 123 patients with GTD were treated primarily with S\&C. After evacuation of molar tissue it was sent for histopathological examination, based on which further management was planned. 
Among these patients, 65 patients (52.8\%) recovered completely without needing any further intervention. They were followed up for at least 6 months and serial hCG monitoring was done, with no signs of persistent disease.

Twenty-eight $(22.8 \%)$ patients required repeated S\&C after their primary S\&C, they had no complications due to the repeated procedure. The mean uterine size measured by ultrasound was $11.5 \mathrm{~cm}$ for 28 patients who had repeated S\&C, and $8.1 \mathrm{~cm}$ for those who underwent one S\&C. It is the policy of the department to subject patients to repeated S\&C routinely if the uterine size of more than $10 \mathrm{~cm}$ in greatest diameter, which is equivalent to a 16 week size uterus, is found on clinical examination.

There were $22(17.8 \%)$ patients who eventually developed PTD after having S\&C as primary treatment. They were followed up at the Molar clinic HUSM after the primary treatment and were diagnosed with PTD according to the FIGO criteria (2000). There were no additional complications noted during $\mathrm{S} \& \mathrm{C}$ in this group of patients.

Three patients $(2.4 \%)$ were diagnosed with choriocarcinoma following histopathological examination of molar tissue after the primary S\&C. All three patients were subsequently treated with high-risk EMA-CO regimen.

MTX is the treatment of choice in low risk GTN cases. Complete remission was achieved in $90.2 \%$ of stage I patients and $62.8 \%$ of low-risk stage II and III patients ${ }^{(13)}$.

There were 7 (31.8\%) patients with stage I disease who failed to achieve satisfactory response with MTX alone and eventually required actinomycin $\mathrm{D}$. These patients recovered completely from the disease. In a trial comparing single-agent MTX versus actinomycin D in patients with lowrisk GTN, remission rate for MTX was $53 \%$ compared to $69 \%$ with actinomycin $\mathrm{D}^{(14)}$.

However, due to better tolerability, easy and convenient administration and lesser side effects with an acceptable rate of remission, MTX is still preferred as a first-line therapy in low-risk patients. Higher WHO risk score ${ }^{(4,15)}$ and clinicalpathologic diagnosis of choriocarcinoma are both associated with an increased risk of resistance to single-agent therapy ${ }^{(16)}$. EMA-CO regimen is the treatment of choice in most highrisk cases, including metastatic disease and patients with high risk based on modified prognostic WHO scoring as adapted by FIGO (2012). EMA-CO had $83 \%$ remission rate in patients with metastatic disease and high risk score ${ }^{(9)}$. Other studies reported much higher success rates with the use of EMA-CO in high-risk patients, with complete remission achieved in $90 \%$ of patients with high-risk GTD ${ }^{(17)}$. In this study, 3 patients with choriocarcinoma, including 2 stage I patients, received EMA-CO regimen.

One of these patients had emergency hysterectomy done prior to treatment with EMA-CO due to massive per vaginal bleeding, while another patients received only EMA-CO after S\&C. Both patients had choriocarcinoma confirmed by histopathological evaluation.

Another patient had stage IV disease with brain and liver involvement. She was started on EMA-CO, but eventually died. The remaining 2 patients achieved complete remission after treatment with EMA-CO.

The success rate of EMA-CO in high-risk patients at our center remains good as seen in previous studies. EMA-CO is well tolerated and it is rarely suspended due to toxicity. Considering high success rates, it is expected to remain the gold standard at least for the coming years.

In the total group of 123 patients, we have recorded an impressive complete recovery rate of $98.4 \%$, while 2 patients (1.6\%) with stage IV disease died. In general, patients with GTD have good prognosis compared to other malignancies. The disease is very chemosensitive, and thus easily treatable. Furthermore, owing to advances in imaging equipment and readily available tumor makers, the diagnosis of GTD can be made early, which is essential for successful treatment.

\section{CONCLUSION}

In this study, significant risk factors included age, high parity, and long interval since last child birth. Most patients had FIGO stage I disease, and the response to single-agent MTX treatment allowed for acceptable outcomes. Other patients, who received second-line therapy, also had a complete recovery. Stage II and III patients achieved complete remission with the EMA-CO regimen. MTX remains our first-line treatment in low-risk patients, but the use of actinomycin also proved beneficial in cases of resistance. This study supports the use of EMA-CO in high-risk patients.

\section{Conflict of interest}

All other authors declare no potential conflict of interest.

\section{Acknowledgments}

School of Medical Sciences, University Sains Malaysia. 


\section{References}

1. Soper JT, Mutch DG, Schink JC; American College of Obstetricians and Gynecologists: Diagnosis and treatment of gestational trophoblastic disease: ACOG Practice Bulletin No. 53. Gynecol Oncol 2004; 93: 575-585.

2. Savage P, Williams J, Wong SL et al.: The demographics of molar pregnancies in England and Wales from 2000-2009. J Reprod Med 2010; 55: 341-345.

3. Sebire NJ, Fisher RA, Foskett $M$ et al.: Risk of recurrent hydatidiform mole and subsequent pregnancy outcome following complete or partial hydatidiform molar pregnancy. BJOG 2003; 110: 22-26.

4. Berkowitz RS, Goldstein DP: Presentation and management of molar pregnancy. In Hancock BW, Newlands ES, Berkowitz RS (eds.): Gestational Trophoblastic Disease. Chapman \& Hall, London 1997: 127-142.

5. Ngan HYS, Chan KKL, Tam KF: Gestational trophoblastic disease. Curr Obstet Gynaecol 2006; 16: 93-99.

6. Berkowitz RS, Cramer DW, Bernstein MR et al.: Risk factors for complete molar pregnancy from a case-control study. Am J Obstet Gynecol 1985; 152: 1016-1020.

7. Garner EI, Goldstein DP, Feltmate CM et al.: Gestational trophoblastic disease. Clin Obstet Gynecol 2007; 50: 112-122.

8. Muller CY, Cole LA: The quagmire of hCG and hCG testing in gynecologic oncology. Gynecol Oncol 2009; 112: 663-672.

9. Costa HL, Doyle P: Influence of oral contraceptives in the development of post-molar trophoblastic neoplasia - a systematic review. Gynecol Oncol 2006; 100: 579-585.
10. Lurain JR: Gestational trophoblastic disease I: epidemiology, pathology, clinical presentation and diagnosis of gestational trophoblastic disease, and management of hydatidiform mole. Am J Obstet Gynecol 2010; 203: 531-539.

11. Moodley M, Tunkyi K, Moodley J: Gestational trophoblastic syndrome: an audit of 112 patients. A South African experience. Int J Gynecol Cancer 2003; 13: 234-239.

12. Sebire NJ, Seckl MJ: Gestational trophoblastic disease: current management of hydatidiform mole. BMJ 2008; 337: a1193.

13. Growdon WB, Wolfberg AJ, Goldstein DP et al.: Evaluating methotrexate treatment in patients with low-risk postmolar gestational trophoblastic neoplasia. Gynecol Oncol 2009; 112: 353-357.

14. Alazzam M, Tidy J, Hancock BW et al.: First line chemotherapy in low risk gestational trophoblastic neoplasia. Cochrane Database Syst Rev 2009; (1): CD007102.

15. Berkowitz RS, Goldstein DP, Bernstein MR: Natural history of partial molar pregnancy. Obstet Gynecol 1985; 66: 677-681.

16. Ngan HYS, Seckl MJ, Berkowitz RS et al.: Update on the diagnosis and management of gestational trophoblastic disease. Int J Gynaecol Obstet 2018; 143 Suppl 2: 79-85.

17. Kim BW, Cho H, Kim $\mathrm{H}$ et al.: Human chorionic gonadotrophin regression rate as a predictive factor of postmolar gestational trophoblastic neoplasm in high-risk hydatidiform mole: a case-control study. Eur J Obstet Gynecol Reprod Biol 2012; 160: 100-105. 